\title{
Sistem Kendali dan Strategi Penanganan (Manajemen) Krisis Dalam Kajian Public Relations
}

\author{
Arief Fajar \\ Program Studi Komunikasi, Universitas Muhammadiyah Surakarta
}

\begin{abstract}
The role of Public Relations, especially in aspects of management (Public Relations Management) to handle issues and crises will greatly depend on the type and systems as an organization. According to Anne Gregory at least in Crisis Management, PR is able to communicate to management about the structure of stakeholder from organizations and their characteristics which are expected to support the policy.
\end{abstract}

Keywords: Crisis Management and Public Relations

“Kita Semua Membenci Krisis" (Kasali, 1995: 219)

\section{Pendahuluan}

Sebagian orang memahami Public Relations sebagai aktifitas, sebagian yang lain mengatakan sebagai sebuah profesi. Bahkan ada yang memahami sebagai sebuah institusi (terlembaga) seperti divisi, bagian, departemen, dan biro jasa, hal ini tidak sepenuhnya benar, tetapi juga tidak sepenuhnya salah. Namun akan menjadi persoalan ketika kita berdebat bagaimana sebenarnya bentuk, fungsi, macam dari Public Relations, terlebih untuk membedakan yang mana Public Relations dan bukan Public Relations. Pada muaranya dapat kita simpulkan; untuk melihat keberadaan Public Relations (apakah sudah menerapkan Public Relations atau tidak) dalam sebuah lembaga atau organisasi, kita tidak dapat memberikan ukuran dengan adanya bagian khusus yang menangani aktifitas Public Relations. Ukuran tersebut harus diperluas yaitu sejauh mana organisasi menerapkan fungsi Public Relations secara sistematis.

Padahal, Public Relations atau dalam bahasa awam di Indonesia dipadankan dengan istilah Hubungan Masyarakat, menjadi katarsis mempercepat pembentukan image berbagai kancah bidang. Sebagai contoh; panggung politik, seseorang calon legislator atau pemimpin memerlukan backup peran Public Relations semisal hubungan media (media relations). Hal ini menunjukkan perkembangan Public Relations terjadi persilangan dengan berbagai hal atau subtansi kajian.Bahkan dalam bidang pemasaran, terjadi perpaduan atau bauran yang diperkirakan mematikan unsur pemasaran kontemporer yaitu periklanan. Mari lihat buku karya Al dan Laura Ries, "The Fall of Advertising and The Rise of Public Relations"; memperlihatkan kekuatan Public Relations bukan hanya pada aspek pembentukan citra tetapi 
juga pemasar baik secara sosial maupun keuntungan semata. Sehingga, praktisi dan pengkaji Public Relations dengan gamblang dapat mengatakan Public Relations merupakan bagian terpenting dalam membangun, merawat dan melestarikan sebuah organisasi; bukan lagi penutup kaca cacat organisasi atau pencipta citra.

Dari berbagai rangkuman sumber; baik Cutlip dan Jefkins menyebutkan urgensi keberadaan Public Relations sebagai berikut;

a. Mengkomunikasikan Kebijakan

b. Membangun hubungan efektif melalui komunikasi dan persuasi kepada publik internal maupun publik eksternal

c. Menjawab tantangan perubahan manajemen modern kepuasan publik sebagai pasar

d. Membantu organisasi keluar dari krisis dengan penerapan manajemen krisis (Cutlip, Center, Broom, 2007 dan Frank Jefkins, 2003)

Lalu pertanyaan selanjutnya justru bukan pada bagaimana Public Relations membangun dan merawat institusi. Namun, bagaimana sebuah organiasi mampu dilindungi oleh Public Relations sebagai sistem kendali krisis? Hal inilah yang menjadi acuan penulisan artikel ini.

\section{Selayang Pandang Public Relations}

Sementara ini, banyak sekali definisi tentang Public Relations, dalam tulisan ini, definisi yang akan dijadikan patokan tentu terkait dengan Public Relations dalam lembaga pemerintahan. Sebelumnya, mari kita tarik sebuah pemahaman bersama tentang definisi Public Relations; secara garis besar hanya ada dua kutub terkait konsep Public Relations yang ada di dunia ini yaitu;

a. Versi Amerika dimotori oleh PRSA (Public Relations Society of America); Public Relations dipahami sebagai fungsi manajemen yang membangun dan mempertahankan hubungan yang baik dan bermanfaat antara organisasi dengan publik yang mempengaruhi kesuksesan atau kegagalan organiasi tersebut. (Cutlip et al, 2007: 6).

b. Sedangkan versi Britania (secara luas Anglo Saxon) dimotori oleh IPR (Institute of Public Relations), salah satunya Frank Jefkins; Public Relations diartikan sebagai bentuk komunikasi yang terencana, baik ke dalam maupun ke luar, antara suatu organisasi dengan semua khalayaknya dalam rangka mencapai tujuan spesifik yang berlandaskan pada saling pengertian (Jefkins et al, 2003: 10)

Sehingga, berkaca dari dua versi tersebut keberadaan Public Relations dalam sebuah organisasi sangat ditentukan oleh bagaimana manajemen organisasi itu dalam memahami urgenitas membangun hubungan sinergis dengan publiknya. Pada muaranya dapat kita simpulkan; untuk melihat keberadaan Public Relations (apakah sudah menerapkan Public Relations atau tidak) dalam sebuah lembaga atau organisasi, kita tidak dapat memberikan ukuran dengan adanya bagian khusus yang menangani aktifitas Public Relations. Ukuran tersebut harus diperluas yaitu sejauh mana organisasi menerapkan fungsi Public Relations secara sistematis. Dalam amatan penulis; hal ini sangat ditentukan oleh tipe dan sistem dari sebuah organisasi itu sendiri.

Pada tipe sistem organisasi yang tertutup; fungsi Public Relations bukan bagian yang dominan dan hanya menjadi pelaksana keputusan manajemen. Hal ini 
diasumsikan; Public Relations mempunyai kewenangan terbatas dalam manajemen untuk mempengaruhi lingkungan organisasi dan manajemen organisasi sendiri yang mempunyai kewenangan utama dalam melakukan hal tersebut.

Sedangkan, tipe dan sistem organisasi yang terbuka Public Relations dalam tipe organisasi ini menjalankan peran utama sebagai mediator atau komunikasi yang resiprokal antara organisasi dengan publiknya.

\section{Komunikasi Krisis dalam Kajian Public Relations serta Strategi Penanganan (Manajemen) Krisis}

Ada beberapa hal mendasar mengenai definisi Manajemen Krisis dalam kajian Public Relations, yaitu;

Grapevine (desas desus) atau isu merupakan "komunikasi informal" yang berasal atau bersentral dari hal-hal urgen bagi organisasi, sedangkan secara etimologis, krisis (crisis) berasal dari bahasa Yunani yaitu kata krinein berarti keputusan (Kamus Webster Online Dictionary, 2005, www.merriamwebster.com, diakses 4 September 2010)

Secara terminologi; krisis adalah malapetaka yang dapat muncul secara alami, hasil kesalahan, intervensi, niat jahat. (Argenti, 2009: 31). Sehingga apabila kita tarik sebuah rumusan maka, krisis dapat diakibatkan (di-brakedown) karena dua hal yaitu;

a. Secara alamiah, semisal; bencana alam

b. Akibat kesalahan manusia (human error), semisal; keteledoran, intervensi, dan sebagainya.

A point of great difficulty or danger to the organization, possibly threatening its existence and continuity, and that requires decisive change. (Cornelissen,
2004: 186)

Suatu titik kesulitan atau bahaya bagi organisasi, dapat mengancam keberadaan dan kesinambungan, dan membutuhkan perubahan yang tepat. Sehingga, maksud dari manajemen isu krisis adalah perencanaan, strategi menangani kondisi urgen yang melanda sebuah organisasi baik bersifat alamiah ataupun human error.

Dalam kajian Public Relations, komunikasi krisis merupakan bagian tindakan Public Relations yang terukur untuk menanggapi sebuah situasi krisis yang dapat menghancurkan reputasi sebuah perusahaan atau disebut Public Relations Krisis (crisis public relations). Istilah ini (crisis public relations) pertama kali digunakan Edward Bernays dalam menanggapi tuduhan kepada Standard Oil. (Biagi, 2010: 295).

Sedangkan menurut Anne Gregory setidaknya dalam Risk and Crisis Management, humas mampu mengkomunikasikan kepada manajemen organisasi tentang gambaran stakeholder dan karakteristiknya dimana diharapkan dukungan terhadap kebijakan tersebut.

Konsep mengenai definisi manajemen krisis berimplikasi dalam strategi manajemen krisis dalam kajian Public Relations. Salah satunya model strategi manajemen krisis dari Rhenald Kasali (1995: 225-230), yang mengadaptasi model anatomi krisis Steven Fink, sebagai berikut:

a. Tahap Prodomal

Tahap prodomal sering disebut pula warning stage karena ia memberi sirine tanda bahaya mengenai sintomsintom yang harus segera diatasi. Mengacu pada definisi krisis, tahap ini juga merupakan bagian dari 
turning point bila manajemen gagal mengartikan atau menangkap signal ini, krisis akan bergeser ke tahap yang lebih serius: tahap akut. Sering pula tahap prodomal sebagai tahap sebelum krisis atau precrisis. Tetapi sebutan ini hanya dapat dipakai untuk melihat krisis secara keseluruhan dan disebut demikian setelah krisis memasuki tahap akut sebagai retrospeksi.

b. Tahap Akut

Inilah tahap ketika orang mengatakan : "telah terjadi krisis". Meski bukan disini awal mulanya krisis, orang menganggap suatu krisis dimulai dari sini karena gejala yang samar-samar atau sama sekali tidak jelas itu mulai kelihatan jelas. Dalam banyak hal, krisis yang akut sering disebut sebagai the point of no return. Artinya, sekali signal-signal yang muncul pada tahap peringatan atau prodomal stage tidak digubris, ia akan masuk ke tahap akut dan tidak bisa kembali lagi. Kerusakan sudah mulai bermunculan, reaksi mulai berdatangan, dan isu menyebar luas.

Namun, beberapa kerugian lain yang akan muncul amat bergantung dari aktor yang mengendalikan krisis. Salah satu kesulitan besar dalam menghadapi krisis pada tahap akut sekalipun sangat siap adalah intensitas dan kecepatan serangan yang datang dari berbagai pihak yang menyertai tahap ini. Kecepatan ditentukan oleh jenis krisis yang menimpa perusahaan, sedangkan intensitas ditentukan oleh kompleksnya permasalahan. Tahap akut adalah tahap antara, yang paling pendek waktunya bila dibandingkan dengan tahap lainnya. Bila ia lewat, maka umumnya akan segera memasuki tahap kronis. c. Tahap Kronik

Tahap ini sering juga disebut sebagai the clean of phase atau the post mortem. Sering pula tahap ini disebut sebagai tahap recovery atau self analysis. Di dalam perusahaan, tahap ini ditandai dengan perubahan struktural baik penggantian manajemen, penggantian pemilik, memasukkan nama-nama baru sebagai pemilik atau dilikuidasi. Crisis manager harus mampu memperpendek tahap ini karena semua orang sudah merasa letih, juga pers sudah mulai bosan memberitakan kasus ini. Namun, yang paling penting adalah perusahaan harus memutuskan mau hidup terus atau tidak. Kalau ingin hidup terus tentunya ia harus sehat dan mempunyai reputasi yang baik. Tahap kronik adalah tahap yang terenyuh. Kadang-kadang dengan bantuan konsultan krisis yang handal, perusahaan akan memasuki keadaan yang lebih baik, sehingga pujian berdatangan dan penyembuhan atau resolution mulai berlangsung.

d. Tahap Resolusi atau (Penyembuhan)

Tahap ini adalah tahap penyembuhan atau pulih kembali dan tahap terakhir dari empat tahap krisis. Meski bencana besar dianggap sudah berlalu, crisis manager tetap perlu berhati-hati, karena riset dalam kasus-kasus krisis menunjukkan bahwa krisis tidak akan berhenti begitu saja pada tahap ini. Krisis umumnya berbentuk siklus yang akan membawa kembali keadaan semula atau prodomal stage.

Masing-masing tahap tersebut saling berhubungan dan membentuk siklus. Lamanya masing-masing tahap itu sangat bergantung pada sejumlah variabel, siklus krisis berpola dapat dilihat dalam 
bagan berikut ini :

\section{Contoh Kasus; Analisa Sistem Kendali dan Strategi Penanganan (Manajemen) Krisis PT Newmont Minahasa Raya ${ }^{1}$}

PT Newmont Minahasa Raya (NMR) mempunyai sistem kendali dan mengembangkan strategi penanganan krisis dengan beberapa pendekatan. Salah satunya akan penulis analisis berdasarkan model strategi manajemen krisis dari Rhenald Kasali (adaptasi model anatomi krisis Steven Fink), sebagai berikut;

\section{a. Tahap Prodomal}

Kegagalan NMR mendeteksi tandatanda akan adanya isu-isu ditahap awal, dan untuk tidak membiarkan isu-isu berkembang menjadi krisis terutama krisis lingkungan, yaitu;

- Prosedur dan lokasi Sistem Pembuangan Tailing Dasar Laut (SPDTL) yang berada di lapisan awal zona termoklin yaitu pada kedalaman 82 (delapan puluh dua) meter. Padahal sesuai analisa dampak lingkungan, lokasi pembuangan limbah harus sedalam 150 meter di bawah termoklin.

- Pembuangan tailing yang salah, menyebabkan kerusakan ekosistem laut berupa:

i. Kekeruhan yaitu pada zona euphotic, di mana pada zona tersebut terdapat lingkungan fitoplankton (produsen) yang butuh sinar matahari sebagai proses fotosintesis;

1 Berdasarkan kajian dan adaptasi tulisan Ulul Azmi, dkk, 2009, Peranan Public Relations dalam Menangani Krisis Lingkungan (Study Kasus: Pencemaran Teluk buyat), Materi Presentasi Kuliah pada Program Magister Ilmu Komunikasi-Sekolah Pascasarjana Universitas Sahid Jakarta, http://www. scribd.com/doc/27620791/Management-PublicRelation-Presentasi-Penanganan-Krisis-KasusTeluk-Buyat-Indonesia\#source:facebook, Diakses 4 September 2010. ii. Penurunan jumlah dan kualitas keberadaan terumbu karang di Teluk Buyat;

iii. Bioakumulasi (penumpukan terus menerus di dalam tubuh mahkluk hidup) dari sedimen pada biota laut di daerah euphotic;

iv. Penurunan kandungan bentos dan plankton (fitoplankton dan zooplankton) akibat tingginya kadar Arsen (As) pada sedimen di Teluk Buyat; dan Kematian ikan dalam jumlah lebih dari 100 (seratus) ekor di sekitar pipa pembuangan tailing di Teluk Buyat maupun terdampar di pantai

v. Kesehatan masyarakat Buyat yang menurun dan berbagai macam penyakit menyerang tubuh mereka, akibat konsumsi air minum dan ikan yang mengandung logam berat (As dan Mn).

- Tidak adanya surat ijin dari Kementerian Lingkungan Hidup

- Dalam pembuangan limbah ke laut maupun pengolahan limbah (B3)

b. Tahap Akut

Periode Krisis Akut benar-benar terjadi, Komunikasi adanya krisis yang ditempuh PT Newmont Minahasa Raya dalam menangani kasus pencemaran di Teluk Buyat tidak mengindahkan konsep-konsep komunikasi yang baik sehingga dapat dikatakan komunikasi korporat perusahaan pertambangan emas ini tidak berhasil. Adanya keterlambatan dalam mengambil keputusan yang dilakukan PT. NMR dalam menerapkan komunikasi sejak awal, yaitu ketika media memberitakan masalah dugaan pencemaran Teluk Buyat oleh PT. NMR pada Juli 2004. 
Komunikasi tentang krisis yang semestinya ditempuh harus bersifat proaktif dan tidak defensif. Selanjutnya, petugas Public Relation juga harus digunakan dalam mencapai solusi dan juga harus melakukan pendekatan Community Relations. Selain itu, penyelesaian krisis PT. NMR tidak melewati tahap pengumpulan pendapat dan keterlibatan masyarakat juga melihat belum adanya manajemen komunikasi krisis dalam penyelesaian kasus pencemaran Teluk Buyat.

c. Tahap Kronik

Strategi Penanganan krisis NMR, diantaranya;

- Strategi terkait dengan Kebijakan Pemerintah

i. PT. NMR, Berusaha untuk meminta pemerintah agar menata kesesuaian kebijakan antara pusat dengan daerah.

ii. Bersama-sama membantu pemerintah untuk proses pendanaan dalam melaksanakan pengawasan dan pembinaan Teluk Buyat.

iii. Bersama-sama pemerintah, membuat sebuah peraturan yang jelas, untuk pemantauan lingkungan dan pengkajian ulang mekanisme izin pembuangan tailing ke laut, serta mekanisme pemberian rekomendasi.

iv. Meminta pemerintah untuk mempublikasikan tindaklanjut izin pengolahan limbah terkait AMDAL, sehingga kedepannya diharapkan tidak ada lagi, kesimpangsiuran, dan dis-orientasi kepada pihak investor, yang ingin menginvestasikan dananya di Indonesia. v. Meminta pemerintah untuk membuat peraturan di masa mendatang, mampu menjelaskan jenis limbah dan peraturan yang terkait, serta membuat laboratorium yang memiliki kemampuan untuk menunjang dalam analisis.

vi. Menyarankan kepada pemerintah, untuk segera mempublikasikan hasil temuan kepada masyarakat, sehingga diharapkan masyarakat dapat memperoleh informasi yang benar terkait dengan kasus teluk Buyat ini.

- Strategi terkait dengan Masyarakat

i. Skala Lokal

$\checkmark$ Berupaya untuk membersihkan laut yang tercemar, agar membantu kesejahteraan masyarakat di teluk Buyat kembali bangkit.

$\checkmark$ Ikut memantau lingkungan dan sumber makanan sekitar teluk Buyat, dan berusaha proaktif mengevaluasi indikasi pencemaran lingkungan, lalu ikut serta dalam proses memperbaiki lingkungan masyarakat sekitar.

$\checkmark$ Mengadakan pengobatan gratis bagi masyarakat sekitar teluk Buyat.

$\checkmark$ PT. NMR berencana di tahun 2010, untuk menanam massal tanaman Mallee, di sekitar pesisir Teluk Buyat, dengan tujuan untuk mereduksi karbon, merkuri dan zat tercemar di laut lainnya. (suara batu hijau Edisi XIII - 2009).

ii. Skala Nasional

Ikut mendanai / mensponsori kegiatan promosi pariwisata 
Teluk Buyat dengan mengikut sertakan peserta dari seluruh Indonesia.

$\checkmark$ Ikut mensponsori kegiatan penyelaman nasional di Teluk Buyat.

- Strategi terkait dengan Sponsorship dan Publikasi

i. PT. NMR mengadakan kegiatan sponsorship berbagai kegiatan lingkungan, contohnya: Seminar Nasional Biologi Tahunan, Penanaman sejuta pohon,

ii. PT NMR ikut berpartisipasi dalam kegiatan pameran lingkungan.

iii. PT NMR ikut berpartisipasi dalam kegiatan promosi Pariwisata Sulawesi Utara.

iv. PT. NMR mempublikasikan kegiatan-kegiatan yang terkait dengan "kepedulian terhadap lingkungan".

- Strategi terkait dengan Riset

PT. NMR memberikan kesempatan kepada berbagai laboratorium, untuk melakukan pengujian terkait pencemaran zat di Teluk Buyat.

\section{d. Tahap Resolusi atau (Penyembuhan)}

Pelajaran yang dapat dipetik dari krisis teluk Buyat ini untuk kedepannya, supaya NMR dapat mendeteksi tandatanda akan adanya isu-isu ditahap awal, dan untuk tidak membiarkan isuisu berkembang menjadi krisis. Untuk NMR supaya lebih paham bahwa masyarakatpun mengalami perubahanperubahan, dimana secara demokratis mereka dapat menyuarakan serta mengekspresikan isi suara hati mereka, terutama jika menyangkut kesejahteraan rnasyarakat. Untuk supaya NMR lebih mengerti bahwa setiap stakeholder mempunyai agenda masing-masing. Oleh karena itu selain re-active, NMR dituntut untuk lebih pro-active, selalu dalam keadaan siap. Untuk menghadapi krisis, diperlu perencanaan yang matang, oleh karena hal itu expect the unexpected.

Masing-masing tahap di dalam krisis PT. NMR dan membentuk siklus, dapat dilihat dalam bagan berikut ini;

\section{Simpulan}

Dari beberapa pemaparan paper masih banyak kekurangan. Namun dapat ditarik kesimpulan tentang gambaran komunikasi krisis dalam kajian Public Relations mengenai sistem kendali dan mengembangkan strategi penanganan (manajemen) krisis, sebagai berikut ;

Dalam kajian Public Relations, komunikasi krisis merupakan bagian tindakan Public Relations yang terukur untuk menanggapi sebuah situasi krisis yang dapat menghancurkan reputasi sebuah perusahaan atau disebut Public Relations Krisis (crisis public relations). Istilah ini (crisis public relations) pertama kali digunakan Edward Bernays dalam menanggapi tuduhan kepada Standard Oil. (Biagi, 2010: 295). Salah satunya model strategi manajemen krisis dari Rhenald Kasali (adaptasi model anatomi krisis Steven Fink), yaitu Tahap Prodomal, Tahap Akut, Tahap Kronik, Tahap Resolusi atau (Penyembuhan)

\section{Daftar Pustaka}

Buku

Argenti, Paul. 2009. Corporate Communication. Penerjemah Putri Aila Idris. Komunikasi Korporat. Jakarta: Salemba Humanika, 2010.

Biagi, Shirley. 2010. Media/ Impact: An Introduction to Mass Media, 9th Ed. 
Penerjemah Mochammad Irfan dan Wulung Wira Mahendra. Media/ Impact: Pengantar Media Massa, Edisi 9. Jakarta: Salemba Humanika, 2010.

Cornelissen, Joep. Corporate Communications; Theory and Practice. London: Sage Pub., 2004.

Cutlip, M. Scott. et. al. 2006. Effective Public Relations, Ninth Edition. Penerjemah Tri Wibowo. B. S. . 2008. Effective Public Relations, Edisi Kesembilan. Jakarta: Kencana Prenada Media.

Gregory, Anne. 2008. "Public Relations and Management", hal.51-68. Alison Theaker (Ed.). 2008. The Public Relations Handbook. New York: Routledge.

Gregory, Anne. 2008. "Public Relations and Management", hal.51-68. Alison Theaker (Ed.). The Public Relations Handbook. New York: Routledge, 2008.

Jefkins, Frank dan Daniel Yadin. 1998.
Public Relations, Fifth Edition. Penerjemah Haris Munandar. 2003. Public Relations, Edisi Kelima. Jakarta: Erlangga.

Kasali, Rhenald. Manajemen Public Relations: Konsep dan Aplikasi di Indonesia. Jakarta: Grafiti, 1995.

\section{Non Buku}

Anonim. Crisis. Kamus Webster Online Dictionary. 2005. Http:// www. merriam-Webster.com. (diakses 4 September 2010).

Azmi, Ulul. 2009. Peranan Public Relations dalam Menangani Krisis Lingkungan (Study Kasus: Pencemaran Teluk Buyat). Materi Presentasi Kuliah pada Magister Ilmu Komunikasi-Sekolah Pascasarjana Universitas Sahid Jakarta. Http://www.scribd.com/ doc/27620791/Management-PublicRelation-Presentasi-Penanganan-KrisisKasus-Teluk-Buyat-Indonesia. (diakses 4 September 2010). 